\title{
PENGEMBANGAN POTENSI EVENT VENUE DI BALI ZOO, GIANYAR, BALI
}

\author{
Oleh \\ Nelsye Lumanauw ${ }^{1)}$ \& I Gusti Bagus Wirya Gupta ${ }^{2)}$ \\ ${ }^{1}$ Politeknik Internasional Bali \\ ${ }^{2}$ Universitas Ngurah Rai \\ Email: ${ }^{1}$ nelsye.lumanauw@pib.ac.id
}

\begin{abstract}
Abstrak
Masa pandemi Covid-19 telah mengubah pandangan terkait penyelenggaraan pertemuan. Kegiatan pertemuan atau aktifitas di ruang terbuka saat ini menjadi pilihan. Bali Zoo sebagai tempat konservasi satwa menjadi salah satu alternatif untuk tempat kegiatan pertemuan yang tidak biasa atau unik di ruang terbuka. Namun demikian, keberadaan ruang meeting indoor dan outdoor di Bali Zoo belum banyak dikenal oleh masyarakat. Kurangnya promosi menjadi salah satu penyebab. Tujuan penelitian ini untuk mengetahui faktor-faktor apa yang mempengaruhi potensi event venue di Bali Zoo dan strategi pengembangan bagaimana yang harus dilakukan. Penelitian ini menggunakan metode kualitatif yang terbagi menjadi dua kategori yaitu berdasarkan teori dan aplikasinya. Kategori teori mencakup event venue, analisis SWOT, teori resource based view (RBV) dan lingkungan perusahaan. Kategori penerapan mencakup analisis terhadap faktor-faktor internal-eksternal yang mempengaruhi pengembangan potensi penyelenggaraan event di Bali Zoo. Kesimpulan penelitian ini adalah dua puluh faktor internal eksternal dan empat strategi pengembangan untuk Bali Zoo. Keempat strategi pengembangan tersebut, yaitu membuat paket event untuk domestik dan dipromosikan secara virtual, zoom atau travel agent (memanfaatkan kekuatan menjadi peluang), membuat event unik (memanfaatkan kekuatan untuk meminimalisasi ancaman), membuat regular outdoor event sebagai sarana promosi (memanfaatkan kelemahan menjadi peluang), membuat event yang tidak dibuat kompetitor (mengubah kelemahan dan ancama)

\section{Kata Kunci: Strategi Pengembangan, Event Venue, Non-Dedicated Venue \& Resources- Based View.}

\section{PENDAHULUAN}

Pemilihan sebuah lokasi atau venue menjadi salah satu pilihan penting bagi penyelenggara event. Kesesuaian dalam memilih venue membawa dampak atas suksesnya suatu event. Tempat penyelenggaraan pertemuan umumnya dilakukan di ruang tertutup atau gedung khusus, tergantung dari besar kecilnya event. Namun, wabah virus corona atau Covid-19 telah mengubah pandangan terkait penyelenggaraan pertemuan di ruang tertutup yang diduga penyebarannya lebih besar. Kegiatan pertemuan atau aktifitas di ruang terbuka saat ini menjadi pilihan. Bali Zoo sebagai tempat konservasi satwa menjadi salah satu alternatif untuk tempat kegiatan pertemuan yang tidak biasa atau unik di ruang terbuka.
Bali Zoo Park di samping sebagai tempat konservasi satwa, juga penyelenggaraan event venue . Fasilitas event venue meliputi tempat pertemuan di dalam air terjun setinggi 15 meter yang dikelilingi oleh pemandangan satwa liar seperti gajah, harimau, beruang dan orangutan. Tersedia juga tempat melakukan photo diri atau selfie dari ketinggian 15 meter di roof top waterfall. Paket meeting juga dapat dikemas dengan kegiatan outdoor dalam paket outbound training untuk memantapkan teori yang diberikan di kelas. Keunikan fasilitas tersebut belum banyak diketahui publik, sehingga jumlah event di Bali Zoo tidak berjalan optimal. Kurang dikenalnya fasilitas event venue, dikarenakan publikasi terhadap fasilitas dan kegiatan event tersebut tidak dilakukan secara giat pada media sosial seperti produk atraksi 
satwa lainnya. Perbandingan jumlah rata-rata kunjungan wisatawan ke kebun binatang tidak diiringi dengan intensitas diselenggarakannya kegiatan event.

Evaluasi terhadap strategi pengembangan mencakup pertanyaan-pertanyaan seperti fasilitas apa saja yang terdapat di Bali Zoo, berapa ruang meeting yang tersedia, paket meeting apa saja yang ditawarkan, inclusion dan exclusion paket meeting, kegiatan promosi yang sudah dilaksanakan. Jawaban atas pertanyaan-pertanyaan tersebut menggambarkan strategi pengembangan yang selama ini dilakukan perusahaan. Adanya ketidaksesuaian antara upaya strategi pengembangan yang telah dilakukan dengan jumlah event yang ditangani oleh perusahaan, menunjukkan pentingnya penelitian ini dilakukan.

Tahapan evaluasi diawali dengan melakukan identifikasi lingkungan perusahaan, khususnya internal melalui pendekatan resource based view (RBV) guna menggali sumber daya yang dimiliki perusahaan. Selanjutnya, faktor lingkungan internal dan eksternal dianalisa menggunakan matriks Strength Weakness Opportunity Threat (SWOT) untuk menetapkan strategi pengembangan potensi event venue di Bali Zoo.

Langkah-langkah analisis SWOT tersebut seharusnya dilakukan oleh perusahaan secara reguler dalam upaya menghadapi kondisi persaingan yang semakin ketat. Berdasarkan latar belakang tersebut, penelitian ini membahas mengenai strategi pengembangan yang harus dilakukan dalam meningkatkan potensi event venue di Bali Zoo.

\section{LANDASAN TEORI}

\subsection{Event Venue}

Definisi event venue menurut Berners (2019:3) adalah tempat kegiatan atau venue adalah tempat terjadinya suatu peristiwa yang bukan suatu kebetulan tetapi direncanakan dan diatur oleh pengelola peristiwa. Selanjutnya, tempat tersebut bisa disebut tempat kegiatan, walaupun digunakan hanya untuk satu kali kegiatan atau peristiwa.
Selanjutnya, Berners (2019:3-7) mengungkapkan tiga tipe venue, yaitu: (a) Dedicated Venue, tempat yang dibangun khusus dengan tujuan, untuk pementasan atau menangani suatu peristiwa, atau disebut juga a purpose-built venue. (b) Non-Dedicated Venue adalah tempat yang dibangun tidak khusus untuk tujuan suatu peristiwa, tetapi bisa digunakan sesuai dengan ukuran, lokasi, fasilitas dan keindahan arisekturnya. Tempat ini biasanya bukan sebagai bisnis utama, melainkan hanya sebagai penunjang bagi perusahaan. (c) Unusual Venue termasuk juga dalam non-dedicated venue, tetapi jarang sekali diadakan suatu kegiatan atau bahkan tidak pernah.

\subsection{Analisis SWOT}

Analisis SWOT menurut Griffin (2004:249) adalah mempertimbangkan kekuatan, kelemahan, kesempatan dan ancaman yang dimiliki organisasi, sehingga (a) suatu organisasi dapat memilih strategi yang mendukung misinya dan mengeksploitasi kesempatan dan kekuatannya, (b) menetralisir ancaman-ancamannnya, (c) menghindari kelemahannya.

Menurut Sarsby (2016:8-10), SWOT terdiri dari faktor internal dan eksternal. Faktor internal adalah faktor-faktor yang bisa dikontrol oleh perusahaan, yaitu unsur strengths dan weaknesses. Faktor eksternal adalah faktor-faktor di luar kontrol perusahaan, yaitu unsur opportunities dan threats. Unsur strengths, opportunities merupakan faktor yang bisa mengatasi unsur weaknesses, threat dan membantu organisasi pada kesuksesan. Unsur weaknesses dan threats merupakan faktor yang membahayakan bagi perusahaan.

\subsection{Resources Based View}

Pandangan berbasis sumber daya atau RBV menurut Pierce dan Robinson (2007:215), merupakan metode untuk menganalisis dan mengidentifikasi keunggulan strategis suatu perusahaan yang didasarkan pada tinjauan terhadap kombinasi dari asset, keahlian, kapabilitas dan asset tak berwujud yang spesial sebagai suatu organisasi. Asumsi yang mendasar RBV adalah perusahaan berbeda secara fundamental karena setiap 
perusahaan memiliki sumber daya yang unik, berupa asset berwujud dan tidak berwujud serta kapabilitas organisasional untuk memanfaatkan aset tersebut.

Definisi resources based view menurut Eikelenboom (2005:16) "The RBV assumes that firms can be conceptualized as bundles of resources, that those resources are heterogeneously distributed across firms and that resource differences persist over time". RBV mengasumsikan perusahaan dapat dikonseptualisasikan sebagai kumpulan sumber daya yang didistribusikan secara heterogen dan bertahan seiring dengan waktu.

\subsection{Lingkungan Perusahaan}

Pengembangan berkaitan dengan upaya untuk melakukan analisis terhadap lingkungan. Kegiatan analisis lingkungan biasanya digunakan untuk membantu organisasi mencapai tujuannya secara efektif dan efisien (Hubeis dan Najib, 2014:64). Tindakan ini dilakukan agar perusahaan dapat mengantisipasi lingkungannya, sehingga bisa bereaksi dengan tepat terhadap perubahan yang terjadi.

Lingkungan perusahaan menurut Purnaya (2016:33-35) dibedakan menjadi lingkungan eksternal dan lingkungan internal. Lingkungan eksternal perusahaan adalah faktor-faktor di luar dunia usaha yang mempengaruhi kegiatan perusahaan dan terbagi menjadi dua, yaitu makro tidak berpengaruh langsung dan mikro berpengaruh langsung. Lingkungan internal perusahaan adalah faktor-faktor yang berada dalam kegiatan produksi dan langsung mempengaruhi hasil produksi.

\section{METODE PENELITIAN}

Metode yang digunakan dalam penelitian ini adalah kualitatif. Metode kualitatif digunakan untuk menganalisis lingkungan perusahaan yang terdiri dari faktor-faktor internal melalui teori Resources Based View dan faktor-faktor eksternal yang berpengaruh terhadap Bali Zoo. Selanjutnya faktor-faktor internal dan eksternal diidentifikasi melalui analisis SWOT untuk menguraikan kekuatankelemahan dan peluang-ancaman yang dihadapi perusahaan. Penerapan metode kualitatif dalam penelitian ini, menghasilkan strategi pengembangan yang tepat untuk meningkatkan potensi event MICE di Bali Zoo.

Lokasi penelitian ini dilakukan pada destinasi wisata Bali Zoo yang terletak di Jalan Raya Singapadu, Desa Sukawati, Kabupaten Gianyar sebagai obyek penelitian.

Penelitian ini menggunakan data kualitatif, guna menguraikan faktor-faktor lingkungan perusahaan yang mencakup internal dan eksternal. Data kualitatif berupa uraian informasi yang diperoleh dari informan dan responden, seperti produk dan paket meeting di Bali Zoo, strategi pengembangan yang dilakukan perusahaan. Sumber data primer dan sekunder menjadi acuan dalam proses penelitian ini. Data primer diperoleh secara langsung dari informan dan responden, untuk mengetahui strategi pengembangan yang telah dan sedang dilakukan oleh perusahaan. Data sekunder diperoleh dari publisitas perusahaan dan instansi terkait, seperti website, instagram dan facebook Bali Zoo dan Badan Pusat Statistik.

Penelitian ini menggunakan instrumen pedoman wawancara untuk memperoleh data yang diperlukan. Pedoman wawancara kepada informan terkait gambaran umum dan penerapan strategi pengembangan yang dilakukan oleh perusahaan. Sedangkan pedoman wawancara kepada responden berupa, pengetahuan tentang Bali Zoo dan penerapan sapta pesonanya.

\section{HASIL DAN PEMBAHASAN Gambaran Umum}

Kebun binatang Bali Zoo mulai dibangun pada tahun 1996 oleh Bapak Anak Agung Gde Putra selaku pemilik dan selesai pada bulan September 2002 setelah enam tahun kemudian. Kemunduran pariwisata terjadi saat bencana bom Bali, mengakibatkan kebun binatang yang baru selesai sepi pengunjung. Namun demikian, pemilik tetap bertahan dengan komitmen konservasi. Awal dibangun, luas area Bali Zoo adalah 3 hektar, kemudian menjadi 13 hektar pada tahun 2002, saat ini sudah menjadi 22 hektar.

Berbagai terobosan diupayakan Bali Zoo, 
termasuk pengembangan Kampung Sumatera pada tahun 2017 yang didalamnya terdapat fasilitas ruang pertemuan berupa gedung dengan air terjun setinggi 15 meter dikelilingi pemandangan satwa gajah, beruang, harimau dan orangutan. Penambahan fasilitas ini menjadikan Bali Zoo tidak saja destinasi wisata satwa tetapi juga tempat penyelenggaraan event.

\section{Faktor-faktor yang Mempengaruhi Pengembangan Potensi Event Venue}

1. Bali Zoo sebagai destinasi pariwisata Berdasarkan observasi, Bali Zoo memiliki atribut destinasi pariwisata, sebagai berikut:

a. Accesibillity: Lokasi Bali Zoo sangat strategis, karena berada di tengah kawasan objek wisata Gianyar, Bali. Keberadaan lokasi yang strategis, memungkinkan pengunjung bisa mengunjungi destinasi lain tanpa menghabiskan waktu panjang. Daya tarik utama pada accesibility dari kebun binatang ini terletak pada tata letak dan desain taman dengan jalur tempat jalan pengunjung yang tertata dan terarah. Jalur pengunjung tertata bagus, sehingga membuat pengunjung yang pertama kali mengunjungi Bali Zoo tidak akan kebingungan.

b. Attraction or entertainment: Sejak dibuka pada tahun 2002, Bali Zoo Park menyediakan berbagai atraksi satwa untuk berbagai kalangan usia. Atraksi satwa dibagi menjadi 2 kategori, animal show para satwa menunjukkan kepintarannya dan keeper talk para satwa mendapatkan instruksi dari pemandu untuk melakukan atraksi. Kedua atraksi tersebut dilakukan setiap hari pada jamjam tertentu sesuai jadwal.

c. Amenities and affordability: Bali Zoo telah menyediakan sarana penunjang lengkap dan memadai. Pintu masuk dan loket tiket berada di halaman depan, bersebelahan dengan area drop-off dan area parkir yang cukup luas. Di area tersebut juga terdapat papan ramburambu informasi tentang satwa. Memasuki area satwa, pengunjung akan disuguhkan taman dengan konsep hutan tropis dan terkesan alami sebagai habitat binatang hutan untuk hidup, bahkan bisa berkembang biak dengan baik.

d. Ancillary service: fasilitas pendukung disediakan oleh Bali Zoo untuk kenyamanan pengunjung, meliputi: ruang terbuka ideal untuk penyelenggaraan event, kerja sama dengan asuransi PT. Jasaraharja Putra, lolos verifikasi dan menerima sertifikat Protokol Tatanan Kehidupan Era Baru Usaha Pariwisata Dinas Pariwisata Kabupaten Gianyar.

\section{Aspek Sapta Pesona}

Berdasarkan observasi, unsur-unsur sapta pesona di Bali Zoo adalah sebagai berikut:

a. Aman, bentuk penerapan keamanan bagi pengunjung maupun binatang, yaitu terdapat papan peringatan keamanan yang menunjukkan kegiatan mana yang diperbolehkan dan tidak diperbolehkan.

b. Tertib, sebelum memasuki area satwa, pengunjung harus menjalankan pengecekan terkait protokol cleanliness, health, safety, environtment (CHSE). Setelah proses registrasi pengunjung mendapatkan brosur terkait informasi dan peta Bali Zoo, sehingga saat berada di area satwa pengunjung dengan tertib melakukan eksplorasi. Namun demikian, perlu ada petugas atau penjaga di beberapa sudut taman untuk membantu pengunjung apabila membutuhkan sesuatu.

c. Bersih, terdapat tempat-tempat sampah di beberapa area kebun binatang, sehingga memudahkan pengunjung membuang sambah untuk kebersihan lingkungan. Namun demikian, ada sampah-sampah dari pengunjung yang tidak disiplin. Oleh karenanya perlu ada papan pengingat untuk tidak membuang sampah sembarangan.

d. Sejuk, konsep hutan tropis yang diusung Bali Zoo membuat tempat ini sejuk dan nyaman, ditambah tersedianya beberapa kolam. Kampung Sumatera mengambil konsep lebih modern, sehingga menimbulkan suasana berbeda dengan 
konsep hutan tropis pada area satwa. Di samping itu, pohon-pohon masih dalam proses pertumbuhan sehingga suasana di Kampung Sumatera tidak sesejuk di area satwa.

e. Indah, konsep hutan tropis dengan berbagai tanaman yang ditata baik di dalam maupun luar kandang, membuat lingkungan Bali Zoo tampak indah.

f. Ramah, sikap ramah dan tindakan memberian pertolongan ditunjukkan oleh karyawan terhadap wisatawan yang ditemui di area kebun binatang.

g. Kenangan, pengunjung bisa menyaksikan atraksi satwa pada jam yang sudah ditentukan, sehingga menimbulkan kesan indah untuk dijadikan kenangan. Kenangan berupa photo atau boneka satwa juga terdapat di area kebun binatang, sehingga pengunjung bisa membawanya pulang.

3. Animal Walfare

Sejak awal berdirinya, perusahan telah berkomitmen untuk menerapkan aturan animal welfare atau kesejahteraan hewan. Aturan animal walfare mencakup standar minimum kesejahteraan satwa yang dilaksanakan. Bali Zoo telah memiliki standard operating procedure terkait hal tersebut dan melaksanakan aturan-aturan di dalamnya.

4. Potensi Event Venue

Bali Zoo memiliki potensi penyelenggaraan event venue yang perlu dikembangkan. Keberadaan ruang pertemuan baik indoor maupun outdoor dan berbagai flora, fauna membuat tempat ini bisa menjadi alternatif menarik untuk melakukan suatu event. Peserta yang ikut dalam penyelenggaraan formal meeting bisa melanjutkan waktu refreshing atau outbound.

Pengembangan Potensi Event Venue

Komponen faktor kunci dalam pengidenfikasian adalah yang memiliki keterkaitan langsung terhadap potensi event venue di Bali Zoo, yaitu sebagai berikut:

1. Identifikasi faktor internal terhadap kekuatan (strengths) potensi event venue di Bali Zoo, mencakup: lokasi strategis berada di kawasan wisata, memiliki ruang pertemuan tertutup dan terbuka, memiliki beragam produk atraksi satwa, fasilitas lengkap, telah mendapat sertifikat terkait CHSE.

2. Identifikasi faktor internal terhadap kelemahan (weaknesses) potensi event MICE di Bali Zoo, mencakup: ruang pertemuan kecil, promosi untuk event venue tidak gencar, saluran distribusi tidak dimanfaatkan maksimal, tidak ada harga khusus untuk wisatawan asing, tidak ada petugas pada sudut-sudut tertentu.

3. Identifikasi faktor eksternal terhadap peluang (opportunities) potensi event venue di Bali Zoo, mencakup: wisatawan dimestik menjadi target saat pandemi ini, promosi melalui virtual tour, membuat paket tour untuk family, manfaatkan zoom untuk penyampaian informasi terkini, bekerja sama dengan berbagai saluran distribusi baik online maupun offline.

4. Identifikasi faktor eksternal terhadap ancaman (threats) potensi event venue di Bali Zoo, mencakup: kompetitor utama memiliki areal lebih luas, keterbatasan SDM, aturan animal walfare, wisatawan asing belum bisa masuk, belum banyak pengunjung yang tahu keberadaan ruang meeting.

Berdasarkan identifikasi faktor internal dan eksternal, faktor-faktor kekuatan dan kelemahan internal yang dimiliki perusahaan, disesuaikan dengan peluang dan ancaman eksternal. Empat tipe strategi pengembangan untuk potensi event di Bali Zoo yang dihasilkan oleh analisis SWOT, mencakup:

1. Strategi Strengths-Opportunities (S-O)

Strategi SO atau kekuatan-peluang terhadap event MICE yaitu membuat paket event untuk domestik dan dipromosikan via virtual, zoom serta travel agent. Bali Zoo memiliki fasilitas yang lengkap sebagai destinasi pariwisata. Namun, belum semua fasilitas dimanfaatkan dengan maksimal. Event venue di Bali Zoo belum banyak dikenal orang. Membuat paket event khususnya untuk wisatawan bisnis domestik bisa menjadi promosi untuk event venue tersebut dan fasilitas lainnya. Promosi yang efektif cepat dan 
tidak mengeluarkan biaya besar adalah melalui media masa, seperti zoom, disamping bekerja sama dengan pihak travel agent. Adanya pandemi Covid-19 membuat sebagian orang memilih aktifitas di rumah. Hal ini menjadi peluang untuk membuat virtual event dengan menampilkan berbagai fasilitas yang ada di Bali Zoo.

2. Strategi Weaknesses-Opportunities (WO)

Strategi WO atau kelemahan-peluang terhadap potensi event venue di Bali Zoo, yaitu membuat regular outdoor event, harga domestik/asing sama dipromosikan melalui semua saluran distribusi. Pandemi Covid-19 telah merubah pola kehidupan masyarakat, diantaranya, sekarang kegiatan outdoor lebih diminati daripada kegiatan yang dilakukan di dalam ruang ber-AC. Keadaan ini bisa menjadi peluang bagi Bali Zoo untuk mengelenggarakan kegiatan outdoor, mengingat terdapat ruang terbuka yang cukup luas. Penyelenggaraan event dengan tidak membedakan pasar domestik maupun asing, sehingga target pengunjung bisa lebih luas lagi. Informasi penyelenggaraan event dilakukan melalui beberapa saluran distribusi sehingga bisa menjangkau pasar yang lebih luas lagi.

3. Strategi Strengths-Threats (S-T)

Strategi ST atau kekuatan-ancaman terhadap potensi event venue di Bali Zoo, yaitu membuat event unik, misalnya pasar murah bekerja sama dengan para petani dari Kintamani atau Bedugul. Pasar murah saat ini sangat diperlukan oleh masyarakat saat ini terkait dengan krisis pandemi. Kesempatan ini bisa dipakai oleh Bali Zoo untuk memperkenalkan kepada masyarakat luas tentang seluruh fasilitas yang dimiliki termasuk ruang pertemuan indoor dan outdoor sebagai tempat penyelenggaraan event.

4. Strategi Weaknesses-Threats (W-T)

Strategi WT atau kelemahan-ancaman terhadap Bali Zoo, yaitu membuat event yang tidak dibuat oleh kompetitor ditujukan untuk domestik maupun asing. Promosi dilakukan melalui saluran distribusi baik online maupun offline. Membuat paket unik yang tidak dibuat oleh competitor menjadi salah satu cara untuk bersaing.

\section{PENUTUP \\ Kesimpulan}

Berdasarkan pembahasan identifikasi lingkungan perusahaan terhadap faktor internal dan eksternal, diperoleh simpulan yang merupakan jawaban dari kedua rumusan masalah dan strategi pengembangan.

Faktor-faktor yang mempengaruhi pengembangan potensi event venue

Faktor-faktor yang mempengaruhi pengembangan potensi event venue di Bali Zoo terdiri dari lingkungan internal dan eksternal, yaitu:

1. Lima faktor kekuatan: pengunjung domestik menjadi target utama untuk melakukan event, melakukan promosi produk melalui virtual tur, membuat paket tur untuk keluarga, manfaatkan zoom untuk penyampaian informasi, melakukan kerjasama online dan offline.

2. Lima faktor kelemahan: ruang pertemuan yang kecil, promosi kegiatan event tidak gencar seperti yang dilakukan terhadap satwa, tidak memanfaatkan saluran distribusi secara maksimum, tidak ada harga khusus untuk wisatawan asing sehingga terjadi keluhan harga mahal, tidak ada petugas pada sudut-sudut taman tertentu menyebabkan pengunjung merasa kesulitan apabila ada hal-hal yang ingin ditanyakan.

3. Lima faktor peluang tersebut adalah: lokasi Bali Zoo strategis dekat dengan kawasan pariwisata lainnya, memiliki dua ruang pertemuan indoor dan outdoor, produk wisata beragam untuk edukasi dan kegiatan event, memiliki fasilitas lengkap seperti restoran akomodasi dan hiburan, perusahaan sudah mendapatkan sertifikat CHSE dan dinyatakan aman untuk dikunjungi.

4. Lima faktor yang menjadi ancaman adalah: kompetitor utama Bali Safari Marine Park yang memiliki área lebih luas dengan keragaman satwa yang lebih banyak, sejak pandemi masyarakat mengalami krisis sehingga semakin selektif dalam menentukan kebutuhan, kebijakan animal walfare membuat beberapa negara 
mengeluarkan peraturan warganya untuk mengunjungi obyek wisata dengan aktivitas satwa, wisatawan belum bisa masuk karena bandara masih membatasi penerbangan dari luar negeri.

Strategi pengembangan potensi event venue

Analisis SWOT menghasilkan empat strategi pengembangan, yaitu:

1. Strategi SO: membuat paket event domestik yang dipromosikan melalui virtual, zoom dan travel agent onlineoffline.

2. Strategi WO: membuat regular outdoor event, harga domestik atau asing disamakan dan dipasarkan melalui saluran distribusi.

3. Strategi ST: membuat event unik yang tidak dibuat oleh kompetitor, seperti pasar murah yang bisa dimanfaatkan untuk mengenalkan fasilitas Bali Zoo dan melakukan promo melalui via online.

4. Strategi WT: membuat event yang tidak dibuat kompetitor dan dipasarkan pada saluran distribusi.

\section{Saran}

Saran-saran yang dapat dianjurkan kepada pihak Bali Zoo demi meningkatkan potensi event venue, adalah:

1. Menggunakan semua saluran distribusi baik online maupun offline. Saluran distribusi akan memberikan berbagai peluang bisnis yang dapat dimanfaatkan dengan baik oleh perusahaan, berupa kreatifitas produk-produk yang dimiliki, baik kegiatan satwa maupun ketersediaan ruang rapat tertutup dan terbuka untuk penyelenggaraaan event. Faktor SDM yang profesional di bidang penyelenggaraan event venue berperan penting terhadap kelancaran saluran distribusi, sehingga berbagai informasi sampai pada penyelenggaran event.

2. Inovasi harus terus dilakukan oleh perusahaan, tidak saja penawaran produkproduk namun informasi edukatif kepada masyarakat melalui sarana virtual ataupun zoom. Hal ini akan membangkitkan kepedulian dan kesadaran masyarakat terhadap satwa, di samping pengetahuan terkait fasilitas-fasilitas yang ada di Bali Zoo, termasuk event venue.

\section{DAFTAR PUSTAKA}

[1] Berners, Philip. 2019. The Practical Guide to Managing Event Venues. New York: Routledge.

[2] Eikelenboom, Bart. 2005. Organizational Capabilities and Bottom Line Performance. Armsterdam: Eburon, Delft.

[3] Griffin, Ricky W. 2004. Manajemen Edisi Ketujuh, Jilid 1. Jakarta: Erlangga.

[4] Hubeis, Musa dan Mukhamad Najib. 2014. Manajemen Strategik dalam Pengembangan Daya Saing Organisasi. Jakarta: PT. Elex Media Komputindo, Kelompok Gramedia.

[5] Pierce, John A, Robinson dan Richard B. Robinson, Jr. 2007. Strategic Management. Manajemen Strategis. Formulasi, Implementasi dan Pengendalian. Edisi 10. Penerjemah: Yanivi Bachtiar dan Christine. Jakarta: Salemba Empat.

[6] Purnaya, I Gusti Ketut. 2016. Ekonomi Dan Bisnis. Yogyakarta: CV Andi Offset.

[7] Sarsby, Alan. 2016. SWOT Analysis, A guide to SWOT for business studies students. UK: Leadership Library. 


\section{HALAMAN INI SENGAJA DIKOSONGKAN}

